PAP

24,3

\section{4}

Received 8 April 2021

Revised 1 October 2021

Accepted 10 October 2021

\title{
How to select good leaders in Asian countries: the case of China and Singapore
}

\author{
Franky K.H. Choi \\ Hong Kong Community College, The Hong Kong Polytechnic University, \\ Hong Kong SAR, China
}

\begin{abstract}
Purpose - The purpose of this paper is to bring out the possibility of selecting good leaders in Asian countries, i.e., China and Singapore.

Design/methodology/approach - Since comparative historical analysis enhances the objectivity for academic discussion, Deng Xiaoping's and Lee Kuan Yew's leadership successions have been chosen as the cases for studies by virtue of "method of agreement". Incorporating "argument based on the contrary" into the context for macro-historical analysis, this paper characterises the duo's successful (at least quite successful) leadership successions, thus offering an alternative paradigm beyond Western-style democracy.

Findings - Both cases of post-Mao China and the independent Singapore indicate that in quite a number of Asian countries, good leaders could still be selected beyond universal suffrage as practised among Western Electoral Democracies, mainly because of the elites-driven context. As to the duo's succession results, Deng Xiaoping's selection of leaders was somewhat successful, while Lee Kuan Yew's was phenomenal.

Originality - This paper offers readers a glance over the possibility of selecting good leaders in Asian countries not fully based on Western-style democracy. Learning from the duo's leadership successions, the West may treat elite politics as the supplement under Western Electoral Democracies in order to avoid their countries falling into the trap of populism. The West could meanwhile consider the exceptional criteria prized by the duo for leadership successions. Considering such interactions among elites in the real-life context, it could serve as an alternative model to Western-style democracy.
\end{abstract}

Keywords China, Chinese Communist Party, Elite politics, Leadership successions, People's Action Party, Singapore

Paper type Research paper

\section{Introduction}

In the twentieth century, one cannot ignore the importance of such alternative paradigms to Western-style democracy in shaping politics in Asia. In an article entitled Totalitarian and Authoritarian Regimes, Linz (1975, p. 264) defined authoritarianism in terms of three critical aspects, namely limited political pluralism tendencies, specific mentality, as well as limited political participation. In this, states without such practice were not likely to undergo enormous political changes unless contingencies, such as serious threats on their leaders' life and/ or HKPAA position, occurred. After the Second World War, the weakened political impact of the Western world on most Asian regions has led to emergence of nation-states. Compared with Western Electoral Democracies, Asian countries not fully practising Western-style democracy had become increasingly popular in Asia. In the lead of political strongmen in such newlyestablished nation-states, those states persisted in political systems of one-party hegemony or even one-party rule. They attempted to establish or change economy and/ or social institutions in the purpose of obtaining legitimacy through good governance. In view of many scholars and

(c) Franky K.H. Choi. Published in Public Administration and Policy. Published by Emerald Publishing Limited. This article is published under the Creative Commons Attribution (CC BY 4.0) license. Anyone may reproduce, distribute, translate and create derivative works of this article (for both commercial and non-commercial purposes), subject to full attribution to the original publication and authors. The full terms of this license may be seen at http://creativecommons.org/licences/by/4.0/legalcode

Public Administration and Policy Vol. 24 No. 3, 2021 pp. 264-274 Emerald Publishing Limited 1727-2645

DOI 10.1108/PAP-04-2021-0028 
populace in the East, the most renowned and influential political strongmen not fully practising Good leaders in Western-style democracy in contemporary Asia were Deng Xiaoping, the second generation's "core" of China, and Lee Kuan Yew, the founding father of Singapore.

Authoritarian regimes are sometimes considered as an alternative to a significant number of countries practising Western-style democracy, including but not limited to the process and result of leadership successions. To certain scholars, authoritarianism does cast a shadow, i.e., with quite a negative connotation followed by their academic beliefs. In this, leadership successions without entirely sticking with the Western experience would be correlated with chaos and instability. For instance, in a book entitled How Communist States Change their Rulers, such a view criticised that when there was power transfer from the old guard to the next generation in communist states, the leadership succession crisis was inevitable (Rush, 1974). More crucially, the author discovered that this political tragedy came from a lack of long-term legitimacy in its authority of decision-making bodies, together with the absence of an institutionalised power transfer mechanism; that could be characterised as a common failure in most, if not all, of the communist states. Yet, starting from 2002, i.e., since the Sixteenth Party Congress in China, its success in leadership successions until the case of Xi Jinping has provided a convincing but counter example of "authoritarian resilience" against the former mainstream perspective. Shambaugh (2008, p. 176) thus praised, "despite its atrophy, I see the Chinese Communist Party as a reasonably strong and resilient institution (I agree with Andrew Nathan's characterisation of the Chinese Communist Party's 'authoritarian resilience'.). To be sure, it has its problems and challenges, but none present the real possibility of systematic collapse". In other words, although Western-style democracy is featured by unshakeable merits, it would not be wise to entirely ignore the bright side of certain Asian perspectives on governance, including but not limited to leadership successions.

A core argument of this paper, particularly with reference to post-Mao China and the independent Singapore, pertains to how we can make every attempt to pick up good leaders beyond Western Electoral Democracies. Thus, leadership successions with less, if not the least, relying on the practice of universal suffrage in the East were picked up as a key issue or as an entry point to discuss how and why some countries not fully practising Western-style democracy could still maintain internal stability during power transfer, including their leaders' capability to obtain legitimacy during the tenures. Since to adopt universal suffrage is a positive means but not a panacea for all socio-economic problems, to achieve the ultimate goal of good governance by alternative ways is indeed an urgent question not simply for Asian countries, but is also noted as the supplement beyond universal suffrage for Western Electoral Democracies.

\section{Leadership successions in China and Singapore}

Different from many Western Electoral Democracies, the governance of most, if not all, Asian countries in the twentieth century was elites-driven. This could be initially explained by their profound impact due to superiority of the party and the state, which was in line with Lijphart's classification of political culture into a political culture of mass and a political culture of elites. Another explanation was that elites could manipulate public opinions via political framing and propaganda. Through monopolistic guidance over the mass media, the framing party could manoeuvre the discussion and perception of a critical issue, such as legitimacy (Guo, 2010, p. 19). Therefore, in certain Asian countries, without taking the factor of universal suffrage into an entire account, elites were further required to take an active role in leadership successions, i.e., changing the top leaders from the old guard to the next generation, such as post-Mao China led by Deng Xiaoping behind the scene and the independent Singapore headed by Lee Kuan Yew. 
With regard to elites' active role in leadership successions, Choi (2017, p. 215) illustrated the next generation leaders preferred by both statesmen mainly according to these criteria: (i) the significance of "expert" as emphasised by Lee Kuan Yew, who considered this criterion as "helicopter qualities" in addition to "support of the new Cabinet's colleagues"; and (ii) the importance of "red" and "expert" as valued by Deng Xiaoping, who broke down both criteria into "Four Modernisations cadres" as well as "adhering to the line of Economic Reform and Open-door Policy and who had some achievements in that respect to their credit". For better understanding, we should note that the aforementioned criteria set by the two paramount leaders in China and Singapore did not have strong correlations with the electoral results from universal suffrage as consistently practised in the West.

As the paramount leader in post-Mao China, Deng Xiaoping valued "Four Modernisations cadres" in addition to "adhering to the line of Economic Reform and Open-door Policy and who had some achievements in that respect to their credit" while appointing his preferred next generation leaders. To consider the connotation of "Four Modernisations cadres", Kou (2010, p. 146) addressed this important requirement with the thorough explanation. For the utmost importance of "red", which Deng Xiaoping coined as "revolutionary standard", it ensured the leadership team would be in the hands of reliable cadres in order to avoid the Cultural Revolution's supporters coming back to power in postMao China; concerning "younger standard", it set up the age configuration of each leading group. The lower the level of cadres, the younger the age. In light of this, the leading groups on all levels showed trapezoidal distribution. As for "better educated and professional standards", the ruling party strived to improve both the knowledge and the wisdom of the potential leaders. Of all standards, Deng (1994, p. 361) prized "revolutionary standard", and explained its utmost importance in detail, "while making sure that we select cadres who will keep to the socialist road, we must reduce their average age, and raise the level of their education and professional competence. The cadre system should be gradually improved to ensure this. Of course, cadres must be revolutionary. This requirement takes precedence over considerations of age, education and professional competence". Not only was the significance of "revolutionary standard" exalted, but the subordination of the other three standards was also asserted. Moreover, this political strongman still indicated a close relationship between "revolutionary standard" and one's political character: this standard could be objectively evaluated through obedience towards the Central Committee, insistence of Four Cardinal Principles, and the practical action of "adhering to the line of Economic Reform and Open-door Policy and who had some achievements in that respect to their credit". A cadre following the above criteria was regarded as fulfilling "revolutionary standard", whereas any hesitation in the real-life context would be perceived as the failure at complying with this criterion.

Deng Xiaoping proposed "younger standard" for the sake of vitality and morale among cadres occupying critical positions. Yet, promoting younger Party members to prominent positions would contradict the convention (in accordance with qualifications and seniority) through which the Party used to assign jobs. What is more, oppositions to promotion of younger Party members were foreseeable since such an act would change the original power structure and violate vested interests. Regarding such a bottleneck, Deng (1994, pp. $225,265)$ reviled, "we say that the capitalist society is bad, but it doesn't hesitate to discover and utilise talents. One of its traits is that it makes use of anyone who is qualified, regardless of seniority, and this is considered normal. In this respect, our system of cadres selection is outmoded. The seniority system represents a force of habit, and is backward". Afterwards, he went on with a pacified tone, "we veteran comrades should not look down on young people or think they are invariably less competent than we are. In fact, at what age did we ourselves begin our careers? Didn't we start doing significant work in our early 
twenties? Are young people nowadays less intelligent than we were then? I think we ought Good leaders in to be more open-minded and consider the overall interests and the future of our cause. We should make a real effort to discover capable persons, and having found them, give them earnest help". In the meantime, it was impossible to "let some people get rich first", or build a well-off society if a successive leader only possessed proper ideologies and vitality. Deng Xiaoping had recognised such a predicament. As a result, he pragmatically highlighted the importance of "better educated and professional standards", and argued, "Four Modernisations cannot be achieved merely by keeping to the socialist road; we must also master professional knowledge and skills. No matter what job a person has, he must acquire the specialised knowledge it entails and become professional competent [...]Being 'expert' does not necessarily mean one is 'red,' but being 'red' means one must strive to be 'expert'. No matter what one's line of work, if he does not possess expertise, if he does not know his own job but issues arbitrary orders, harming the interests of the people and holding up production and construction, he cannot be considered 'red"' (Deng, 1994, p. 262). Apart from being "red", the working capability possessed by a young successor was still significant, simply because "a person may have ardour for socialist construction, but if he doesn't master professional skills and study conscientiously, he will not be able to make the contribution he should do that construction or play his proper part in it; on the contrary, he may play a negative role" (Deng, 1994, p. 264).

Besides, Lee Kuan Yew, the paramount leader in the independent Singapore, had identified leadership successions as a crucial long-term issue: that he needed to recruit candidates both inside and outside the People's Action Party since 1967. He did not believe all humans were on equal standing in terms of their physicality and intelligence. In this regard, he rejected this kind of common presumption, i.e., everyone could make valuable contributions together with their equal abilities (Josey, 1980, p. 36). Of all candidates, those elitist talents were highly educated and professional; they were thirty something years old and outperformed in their field. Goh Chok Tong and Tan Keng Yam were typical examples. As an old guard leader, the criteria of next generation leaders Lee Kuan Yew valued were "helicopter qualities", including "power of analysis", "logical grasp of the facts" and "concentration on the basic points, extracting the principles" (Han et al., 1998, p. 103). In view of such requirements, Lee Kuan Yew preferred to recruit "problem-solvers" rather than "word-spinners" so as to improve the governance quality (Milne and Mauzy, 1990, p. 116). To be obvious, Lee Kuan Yew strongly believed a capable leader should be a better and skilful debater; and this leader should have academic and professional background, working ability along with positive attitude, and ability to deal with contingencies. Followed by his observation and judgment, this founding father of Singapore needed to decide whether he would let such a candidate continue with his candidacy based on his performance in politics later. Since not all young elitist talents in Singapore could overcome challenges, quite a substantial number of selected candidates were gradually eliminated during the process. Lee Kuan Yew hence explained, "in order to recruit thirty capable elitist talents, we have to select fifty candidates for final screening with twenty eliminated" (Ed. Singapore Joint Morning Paper, 1994, p. 493). At this point, Goh Chok Tong was one of the very few who survived, and became the Prime Minister. Accordingly, "helicopter qualities" would be beneficial to the People's Action Party, who pursued highly efficient administration.

Not only wholly relying on "helicopter qualities" for consideration, but also should Lee Kuan Yew value his successor's relations with other Cabinet's Ministers in the name of "support of the new Cabinet's colleagues". To put it simply, as long as this old guard leader could get along well with his colleagues, he could strike a good balance between stakeholders and his homeland during policy-making. He further pointed out, "the posts of political leaders and civil servants should be taken up by the most suitable candidates. In other words, 
they should have a high level of integrity, devotion, and abilities to lead the country" (Ed. Singapore Joint Morning Paper, 1994, p. 240). In this, Lee Kuan Yew sincerely popularised the wisdom of politics, in particular the human transcendence against the external environment. Therefore, he prized selection and training of elitist talents, and harmonious interpersonal relationships. Obviously, Singapore's leadership succession smoothly proceeded under his long-term planning. After this political strongman handed over his political power in the 1980s, he allowed potential leaders of the second generation to compete freely in this political game; as a result, Goh Chok Tong survived in this unexpected political journey over decades. Goh recently summarised his dramatic succession experience in the memoir, "I was chosen by the second-generation Ministers ('support of the new Cabinet's colleagues') to lead in December 1984. Lee Kuan Yew then appointed me Deputy Prime Minister. But four years later, he publicly declared that I was not his first choice (Tan Keng Yam) as Prime Minister. Whatever his doubts and reasons, my colleagues stood by me. Lee Kuan Yew handed me the premiership in November 1990" (Peh, 2019, p. ix).

\section{Evaluations of passing the batons to next generation leaders}

A method for evaluating the result of leadership successions is to judge from Deng Xiaoping's and Lee Kuan Yew's successors. Prior to evaluating whether their successors succeeded, we should initially understand both the meanings of success in and failure at successions. To go further, the duo's leadership successions included the succession of position, power, and authority. Given that a next generation leader was capable of acquiring the position, power and authority from the political strongman, and coping with the challenges from other candidates or factions without being stepped down, he would then succeed. However, since others could hardly gain the authority itself, one could still succeed accordingly, if he was able to take hold of both the position and the power from an old guard. On the contrary, if the successors merely took one of the three: including position, power and authority from his political strongman, and were forced to leave the office earlier than original settings: including but not limited to house detention, such a succession would be regarded as a failure.

Based on the above-mentioned benchmark for an evaluation, Deng Xiaoping had appointed four candidates as General Secretary, i.e., Hu Yaobang, Zhao Ziyang, Jiang Zemin, and Hu Jintao. For instance, Jiang Zemin received both the highest leadership positions, i.e., both the General Secretary and the Chairman of the Central Military Commission. More significantly, he could complete his entire terms of office. After Jiang Zemin won those top leadership's positions of the Party and the state, his power grew. During the Southern Tour in 1992, Deng Xiaoping had marginalised many potential competitors inside the Chinese Communist Party through his personal authority, so that Jiang Zemin could become the "core" of the third generation leadership with both the positions and the power. Of four successors, the first two were forced to step down despite their unexpired terms of office, while the last two were more successful. Compared with Deng Xiaoping's power transfer arrangement, Lee Kuan Yew's plan to this was mainly the power given and the power of transfer, i.e., letting his successor receive a position and hold the power. No doubt, Deng Xiaoping never possessed a leading position, and, more critically, his personal authority was restricted by life cycle as other humans did. Thus, Deng Xiaoping shaped such a difficult milieu for his successors to compete regardless of his intension. Clearly, Deng Xiaoping's leadership successions encountered a lot more constraints than Lee Kuan Yew's. As a result, the two political strongmen's distinctive arrangements on leadership successions led to different results, i.e., Lee Kuan Yew was considered as an excellent politician to complete this task, while Deng Xiaoping only received the better results from his third and fourth attempts. 
Lessons of good governance in Asian countries for Western Electoral

\section{Democracies}

Influenced by the Westminster system, relationship of nation-states between the East and the West has long been a combination of sweet and sour. Yet, during the twenty-first century, at least in the understanding of the path about political development, such a relationship is increasingly souring. It is believed that this secular trend will continue over the next decade and beyond. As Yip (2012, pp. 171-172) said, "today, there are no confronting ideologies as in the Cold War period. During the Cold War, when two worlds (the East and the West) were hostile to each other [...] Now that the Soviet Union has disintegrated [... The world should opt for integration instead of confrontation. It is not necessary to overemphasise the merits of a democratic political system (in the West) or promote the merits of the China model (one of the Asian models in the East). The two systems can be discussed with an open mind". In other words, once looking into the future, mutual respect, sharing and co-existence among distinctive civilisations are essential, including but not limited to learning some of the good governance lessons in the East in order to contribute to human progression even for Western Electoral Democracies.

\section{To select good leaders beyond Western Electoral Democracies}

Democracy is good in nature, but the understanding of this political term can be diverse regarding its connotation and practice among countries. As Wang (2016, p. 233) explained, our general recognition of democracy could be divided into: representative democracy to highlight democratic featured matters, such as regularly-held universal suffrage (as in the West), and representational democracy to focus on people's essential needs (as in the East). The former, however, is likely to put excessive emphasis on the means, since Bell (2015, p. 16) suggested, "yet political power is an exception: it's fine to pick a leader with no prior political experience, so long as he or she has been chosen on the basis of one person, one vote". In other words, catastrophic results may arise due to excessive procedural justification; and that a democratic society is likely to be haunted by the unwanted consequence. For example, some area specialists suggested that "where democratisation has recently taken place, it is unstable and vulnerable to new rounds of executive actions, military coups, and mass uprisings" (Case, 1996, p. 437). Obviously, the aforementioned consequences, such as riots, could be the unexpected by-products of representative democracy. Jones (2020, p. 9), moreover, added, "the push for 'one person, one vote,' come what may, has had both benefits and costs, and in the twenty-first century we have enough data to make it clear that the costs are pretty high. The costs of giving equal weight to the informed and uninformed alike are high enough that it's worthwhile to look for creative ways to tilt the scales just a little bit toward the informed". That is to say, there is an important presumption for "one person, one vote"; the populace themselves should be informed enough for making sensible and independent voting, one that is not manipulated by certain social media with political leaning. To Jones, however, the costs of fulfilling such a prerequisite are relatively high, in which case the merits of "one person, one vote" are likely to be eaten up by the costs per se. Also, "representation need not mean representative government" (Pitkin, 1967, pp. 2-3) in all spatial-temporal conditions. While we could have distinctive interpretations of democracy, the above-mentioned view implied that such a political term, including but not limited to leadership successions that may have various definitions and developmental paths, should not be entirely related to making good use of universal suffrage for picking up next generation leaders, especially with reference to the scenarios after the leadership of their political strongmen. For passing of the old guard, such as revolutionary leaders of the Chinese Communist Party, the leadership succession issue was increasingly pressing. As the new generation naturally lacked the personal power that their old counterparts shared based
Good leaders in Asian countries 
on their revolutionary experience, they had to build up a new power base by discovering a series of new rules and methods. Take China as an example again, the post-Deng leadership, i.e., Jiang Zemin, Hu Jintao, and currently Xi Jinping, have made enormous efforts to institutionalise such elite politics. Undoubtedly, many formal institutions have been established, but informal rules continued to play a significant role in leadership successions (Zhang, 2009, pp. 72-73).

Regardless of the process of leadership successions in post-Mao China or the independent Singapore, such an approach of both countries was not fully institutionalised. Take Singapore as an example, this Southeast Asian "red-dot" had been through the lead of two Prime Ministers, i.e., Goh Chok Tong, and now Lee Hsien Loong after Lee Kuan Yew's step-down in 1990. Although the founding father of Singapore was no longer the Prime Minister nor the President after 1990, and he further resigned from the post of Secretary General of the People's Action Party in 1992, he was still reelected as a Member of Parliament of Tanjong Pagar constituency, and served as the Senior Minister from 1991 to 2004 and later the Minister Mentor from 2004 to 2011; definitely his off-stage political influence was remarkably obvious behind the scene. Goh Chok Tong explained that he arranged the regularly-held Cabinet meetings to discuss issues with Ministers beyond the Parliament, in which a meeting was divided into two parts, i.e., formal and informal discussions. Although Lee Kuan Yew was not invited to join the first part of the meeting, he could still exercise his residual power by sharing his previous governing experience in the second part (Vasil, 1992, pp. 232-233). Clearly, such a sharing implied that the most critical public policies and personnel appointments required Lee Kuan Yew's final endorsement, whether under the frontline leadership of Goh Chok Tong or Lee Hsien Loong. Then, why did governments in China and Singapore not prefer to opt for such fully institutionalised leadership successions? Among all factors, the current effectiveness of leadership successions and, more importantly, the potential risk of changing the current approach could mainly account for the situation. As Helms (2020, p. 5) suggested, "autocratic successions tend to be of even greater importance in their own right than successions in democratic regimes. While successions in democracies usually represent a more limited form of power change, compared to full-scale democratic transitions (in terms of alternation in government and changing patterns of political control), successions in autocratic contexts often mark the one visible element of change in an otherwise more or less change-averse and closed environment". In other words, some regimes, such as Deng Xiaoping's and Lee Kuan Yew's nations, were likely to perpetuate the current political mechanism, because the nature of such regimes not fully practising Western-style democracy went against changes, especially significant ones; and such a feature could be exemplified by specific mentality.

First, after more than half a century, the developmental path of leadership successions of both countries has retained the characteristics of the traditional political system; at the same time, it has also been adjusted due to political modernisation. At present, the leadership successions are no longer full of violence or noted as a zero-sum game. Changing the mode of leadership successions to terminate the current governors to recruit or even appoint successors is not a rational option for the ruling parties; instead, most rational top leaders are inclined to preserve the existing mechanism in order to maintain their legitimacy, including the process of leadership successions. As for the governed of some countries not fully practising Western-style democracy, they do not have the strong motives to completely subvert the existing system, mainly because the leadership succession issue has always been manipulated by the elites but not the populace within the boundaries.

Second, the democratic transition including but not limited to leadership successions in many non-democratic countries, such as the Soviet Union and a series of post-communist states in Eastern Europe, did not serve as a good example for the top leaders of China and Singapore. In other words, as there is already some less, if not the least, successful change in 
leadership successions of some countries not fully practising Western-style democracy, to maintain the stability of the existing system is, no doubt, the most considerate option for the utmost interests of China and Singapore.

With regard to an absence of the fully institutionalised leadership succession of some Asian countries, just as the scenarios occurred in China and Singapore, what are the lessons for Western Electoral Democracies? In addition to the practice of regularly-held universal suffrage for selecting new generation leaders, it is, meanwhile, critical to highlight the importance of elite politics as the supplement under Western Electoral Democracies in order to avoid their countries falling into the trap of populism, especially with the emergence of a series of lowquality democratic representatives leading the general public. Clearly, to continuously allow for the "self-renewal" (from the old guard to the next generation) inside the Chinese Communist Party and Singapore's People's Action Party, elite politics has mostly been placed as the top priority starting from the leadership of Deng Xiaoping and Lee Kuan Yew.

First, in terms of the requirements for recruiting or appointing the next generation leaders, such a criterion of "expert" was prized by the old guards in post-Mao China and the independent Singapore, which was also considered the supplement beyond the regularlyheld universal suffrage for Western Electoral Democracies. On the one hand, elites absorbed to the government can be nurtured as technocrats who had earlier received systematic education, together with professional training. Due to quality education, such technocrats, while governing their homelands, can tackle problems rationally and professionally. On the other hand, these individuals are more interested in their professional fields than power struggle in politics. Being experts in their professional fields, they tend to analyse problems not through official ideologies during both the formulation and the implementation of public policies. In other words, practical problems are better not to be solved by the political means.

Second, the ruling parties in China and Singapore were well-established in an elite cooperation mechanism in order to balance the interests of distinctive stakeholders of their countries. Such a practice focused on cooperating different elites both inside and outside the party, especially for attracting economic elites and industrial elites as political elites, i.e., some next generation leaders. Theoretically, the frequent interaction among various elites, in particular representing the interests of their professional fields, may undermine social equity or challenge the implementation of certain public policies. But in the real-life context, being a lesson for Western Electoral Democracies, such an interaction among elites can be characterised as the benign competition under the countries not fully practising Westernstyle democracy. In many situations, elites are required to obey the premise of "consistent basic interests" and have to cooperate in all critical decision-making scenarios, rather than be blunt or confront unreasonably, just as certain legislatures under Western Electoral Democracies for making use of the "filibuster" form of deliberation in order to upset the administrative efficiency. That is to say, whether or not under Western Electoral Democracies, the interaction and the cooperation among different elites both inside and outside the party for formulating and later implementing public policies as expected would guarantee the better legitimate status of the ruling party of that country. More significantly, even under the practice of regularly-held universal suffrage among Western Electoral Democracies, such a mode still deserves mentioning here as it can greatly lower the top leaders' potential risk of encountering "motion of non-confidence", such as being raised by opposition parties in the Parliament. Its successful key in fact can be simply attributed to "never putting all the eggs in one basket", i.e., elites of the ruling party and, meanwhile, different stakeholders of society actively participating in the process of policy-making would share the political risks and responsibilities, if the implementation result of a public policy initiated by the ruling party and its top leaders is unsatisfactory. Thus, in the case of the sudden absent legitimacy of the government, this political tactic is certainly a wise move to supplement the declining 
procedural legitimacy at once, and this is what Western Electoral Democracies can learn from accordingly.

\section{Conclusion}

This paper argues the cases of post-Mao China and the independent Singapore prove that in some Asian countries, good leaders could still be selected beyond Western-style democracy, mainly because of the elites-driven context. From this, the statesmen's criteria for leadership successions are in tandem with (i) the significance of "expert" as emphasised by Lee Kuan Yew, who considered this criterion as "helicopter qualities" in addition to "support of the new Cabinet's colleagues"; and (ii) the importance of "red" and "expert" as valued by Deng Xiaoping, who broke down both criteria into "Four Modernisations cadres" as well as "adhering to the line of Economic Reform and Open-door Policy and who had some achievements in that respect to their credit". Moreover, Deng Xiaoping proposed "younger standard" for the sake of vitality and morale among cadres occupying critical positions. Apart from being "red", the working capability possessed by a young successor was still significant. As to Lee Kuan Yew, he valued a lot more his successor's relations with other Cabinet's Ministers in the name of "support of the new Cabinet's colleagues".

Evaluating the duo's leadership successions, we could gauge the results based on their successors' fulfilment of the proposed criteria and their terms of office. Deng Xiaoping's leadership successions were somewhat successful (with two successful cases as Jiang Zemin and $\mathrm{Hu}$ Jintao) due to the political situation he was facing at the time. In contrast, Lee Kuan Yew's was phenomenal (with his successor taking hold of both the position and the power).

From the duo's selection of leaders, one could discover that their successions were partly institutionalised, because most rational top leaders are inclined to preserve the existing mechanism in order to retain their legitimacy. Additionally, the democratic transition including but not limited to the leadership succession in many non-democratic countries, such as the Soviet Union and a series of post-communist states in Eastern Europe, did not serve as an exemplary case for the top leaders of China and Singapore.

Learning from Deng Xiaoping's and Lee Kuan Yew's leadership successions, the West may treat elite politics as the supplement under Western Electoral Democracies in order to avoid their countries falling into the trap of populism. As Lutovac (2020, p. 51) warned, "populism does not only appear as an 'alternative' to the established parties - it is at the same time infiltrating them as well as society on the whole. The narrative of populism widens the gap between the political class and society, but it does not provide rational answers to the crisis of representative democracy. Populism grows in the atmosphere of political and social divisions and favours the destruction of 'the people's enemy' over compromise". The West could meanwhile consider a series of exceptional criteria prized by the duo for leadership successions. As for the interaction among elites in the real-life context, it could serve as the benign competition under the countries not fully practising Western-style democracy, which the West can learn from.

One might note that during leadership successions, the two political strongmen's personal authorities originated from their charismatic leadership. Since such personal authorities were obtained through historical achievements and also personal charisma, they could constantly receive their followers' loyalty. That kind of personal authority could barely be forwarded to the future leaders. As time passes, during power transfer, i.e., obtaining positions from the duo, successive leaders just had a pinch of power. Their policy-making then took an opulent cavalcade towards the political strongmen's wave of stick. 
To fill the knowledge gap of our existing literature, the significance of this paper lies in offering readers a glance over the possibility of selecting good leaders in Asian countries not fully based on Eurocentric perspective, e.g., overemphasising both the good and the usefulness of having universal suffrage as widely accepted in Western Electoral

Good leaders in Asian countries Democracies.

\section{References}

Bell, D.A. (2015), The China Model: Meritocratic Politics and the Limits of Democracy, Princeton University Press, Princeton.

Case, W. (1996), "Can the 'halfway house' stand? Semidemocracy and elite theory in three Southeast Asian countries", Comparative Politics, Vol. 28 No. 4, pp. 437-464.

Choi, K.H. (2017), The Art of Governance of Authoritarian Leaders in Asia: A Comparative Study of Lee Kuan Yew and Deng Xiaoping, Unpublished Doctoral Thesis, Department of History, The Chinese University of Hong Kong, Hong Kong.

Deng, X.P. (1994), 《鄧小平文選 (第二卷) 》(Selected Works of Deng Xiaoping (Vol. 2)), People's Publishing House, Beijing.

Guo, B.G. (2010), Chinese Quest for Political Legitimacy: The New Equity-enhancing Politics, Rowman and Littlefield, Lanham.

Han, F.K., Fernandez, W. and Tan, S. (1998), Lee Kuan Yew: The Man and his Ideas, Singapore Press, Singapore.

Helms, L. (2020), "Leadership succession in politics: the democracy/ autocracy divide revisited", British Journal of Politics and International Relations, Vol. 22 No. 2, pp. 1-19.

Jones, G. (2020), 10\% Less Democracy: Why You Should Trust Elites a Little More and the Masses a Little Less, Stanford University Press, California.

Josey, A. (1980), Lee Kuan Yew: The Struggle of Singapore, Angus and Robertson, London.

Kou, J.W. (2010), 《中共菩英政治的演變——制度化與權力轉移 (1978-2010) 》 (Evolution of Elite Politics of the Chinese Communist Party: Institutionalisation and Power Transfer (1978-2010)), Wunan Book, Taipei.

Linz, J. (1975), “Totalitarian and authoritarian regimes”, in Greenstein, F.I. and Polsy, N.W. (Eds.), Handbook of Political Science (Vol. 3), Addison-Wesley, Massachusetts.

Lutovac, Z. (2020), Populism, Stabilitocracy and Multiculturalism, Institute of Social Sciences, Belgrade.

Milne, R.S. and Mauzy, D.K. (1990), Singapore: The Legacy of Lee Kuan Yew, Westview Press, Oxford.

Peh, S.H. (2019), Tall Order: The Goh Chok Tong Story (Vol. 1), World Scientific, Singapore.

Pitkin, H.F. (1967), The Concept of Representation, University of California Press, Berkeley.

Rush, M. (1974), How Communist States Change their Rulers, Cornell University Press, Ithaca, New York, NY.

Shambaugh, D. (2008), China's Communist Party: Atrophy and Adaptation, University of California Press, Berkeley.

Singapore Joint Morning Paper (Ed.) (1994), 《李光耀——40年政論選》(Selection of Lee Kuan Yew's Political Essays in 40 Years), Singapore Press Holdings, Singapore.

Vasil, R.K. (1992), Governing Singapore, Mandarin, Singapore.

Wang, S.G. (2016), 《中國政道》 (The Political Way of China), Zhonghua Book Company, Hong Kong.

Yip, K.W. (2012), The Uniqueness of China's Development Model, 1842-2049, World Scientific, Singapore.

Zhang, Y.N. (2009), The Chinese Communist Party as Organizational Emperor: Culture, Reproduction and Transformation, Routledge, London and New York, NY. 
About the author

24,3

Franky K.H. Choi, Ph.D., received his M.Soc.Sc. (Academic Distinction \& Dean's List) from The Chinese University of Hong Kong. His research interests include Chinese Studies, Comparative History \& Politics, Cultural Studies and Sociology. He is a Lecturer under Division of Social Sciences, Humanities and Design of CPCE under The Hong Kong Polytechnic University. In addition to his teaching assignments, he is an Associate Editor of Public Administration and Policy: An Asia-Pacific Journal, and was invited as a Guest Host for a radio programme on Culture, History and Politics at Metro Info (FM 99.7). Franky K.H. Choi can be contacted at: franky.choi@cpce-polyu.edu.hk

For instructions on how to order reprints of this article, please visit our website: www.emeraldgrouppublishing.com/licensing/reprints.htm Or contact us for further details: permissions@emeraldinsight.com 